\title{
An ice-core pollen record showing vegetation response to Late-glacial and Holocene climate changes at Nevado Sajama, Bolivia
}

\author{
C.A. REESE, ${ }^{1}$ K.B. LIU, ${ }^{2}$ L.G. THOMPSON ${ }^{3}$ \\ ${ }^{1}$ Department of Geography and Geology, University of Southern Mississippi, Hattiesburg, MS, USA \\ E-mail: carl.reese@usm.edu \\ ${ }^{2}$ Department of Oceanography and Coastal Sciences, School of the Coast and Environment, Louisiana State University, \\ Baton Rouge, LA, USA \\ ${ }^{3}$ School of Earth Sciences, The Ohio State University, Columbus, OH, USA
}

\begin{abstract}
We present the results of pollen analysis performed on an ice core recovered from Nevado Sajama, Bolivia, dated to $25 \mathrm{ka}$ BP. Low pollen concentrations from 25 to $15 \mathrm{ka} \mathrm{BP}$ are consistent with the scenario of an expanded ice cap surrounded by sparse vegetation and cold conditions on the Altiplano during the Last Glacial Maximum. After $15 \mathrm{ka} \mathrm{BP}$, more pollen is present and percentages show vegetation response to climate fluctuations during the late Pleistocene. Initially, high concentrations of Poaceae pollen are replaced by Asteraceae pollen, suggesting the occurrence of dry conditions towards the end of the Bølling-Allerød/Guantiva interstadial. A deglacial climatic reversal is registered in the pollen record by an abrupt decline in Asteraceae and maximum percentages of Poaceae, indicating wet conditions during 14-12 ka BP. The climate changed abruptly to warm and dry after $12 \mathrm{ka} \mathrm{BP,} \mathrm{but}$ vegetation remained in disequilibrium with climate until $10 \mathrm{ka}$ BP. Pollen results indicate dry conditions at the beginning of the Holocene, with humidity increasing steadily until $8.5 \mathrm{ka} \mathrm{BP}$. Decreased pollen concentration values (used as a moisture availability proxy) place the mid-Holocene dry period between 8 and 5 ka BP. This was followed by wetter conditions to the present day.
\end{abstract}

\section{INTRODUCTION}

The impact of Late-glacial and Holocene climate change on the hydrology and vegetation of the central Andes has been researched for decades but continues to produce a significant amount of debate (e.g. Baker and others, 2001; Grosjean, 2001; Quade and others, 2001; Mourguiart and Ledru, 2003). Because of its complex topography, diverse ecosystems and sensitive circulation regime (Zhou and Lau, 1998; Garreaud, 1999, 2000; Vuille, 1999; Garreaud and others, 2003), the region does not respond uniformly to climate change, and thus many paleoenvironmental records are contradictory or asynchronous (e.g. Abbott and others, 2003). In addition, questions remain as to the centennial- to millennial-scale forcing mechanisms that are responsible for these changes (Hillyer and others, 2009). More temporally long and high-resolution records are needed from the region to reconstruct an accurate paleovegetational history. This is especially true for records that contain biological proxies (pollen, phytoliths, macrofossils, etc.) because vegetation change is best interpreted through direct evidence. However, most pollen, phytolith and macrofossil studies conducted in the central Andes have been based on lake/bog sediments (Hansen and others, 1984, 1994; Hansen and Rodbell, 1995; Chepstow-Lusty and others, 2003, 2005; Paduano and others, 2003; Bush and others, 2005; Hanselman and others, 2005; Weng and others, 2006; Gosling and others, 2008) or rodent middens (Holmgren and others, 2001; Latorre and others, 2002, 2003) and many are limited by their temporal range, temporal resolution or both.

Tropical Andean ice cores contain long temporal records of past environmental conditions and can be analyzed at high resolution (Thompson and others, 1995, 1998, 2006).
The chemical and physical proxies commonly used in icecore research reveal physical conditions of the past (e.g. paleotemperature, paleoprecipitation and paleocirculation), but do not provide direct evidence of vegetation change. Though fossil pollen grains are abundant and ubiquitous components of these ice cores (Liu and others, 1998, 2005, 2007), a systematic long-term pollen record has yet to be produced. Here we present a $25 \mathrm{ka}$ ice-core pollen record from Nevado Sajama, western Bolivia. This research expands on previous pollen studies from the Sajama ice cap (Liu and others, 2005, 2007), which have shown pollen assemblages to be sensitive indicators of vegetation change at shorter (i.e. decadal to centennial) timescales. Our aim in this paper is to assess the sensitivity of this biological proxy in tropical ice cores over longer temporal ranges.

We begin this investigation with an overview of the study area and discuss the patterns of vegetation in the central Andes and the physical factors (e.g. precipitation, temperature, regional circulation regimes) that influence them. Next, in the methodology, we discuss the ice cores that were extracted from Sajama in 1997 and give a detailed description of our pollen-processing and -counting procedures. In the results and discussion, we present and discuss our findings from the pollen analysis on the Sajama ice core and show that pollen is a sensitive indicator of vegetation response at these longer temporal ranges. Finally, in the conclusion, we compare our findings at Sajama to the results of other regional paleoenvironmental records to highlight the patterns of climatic changes and vegetation response in the central Andes during the Late-glacial and Holocene periods. We also discuss the limitations of pollen as an ice-core proxy, as well as the unique contributions that pollen analysis adds to an ice-core paleoenvironmental record. 


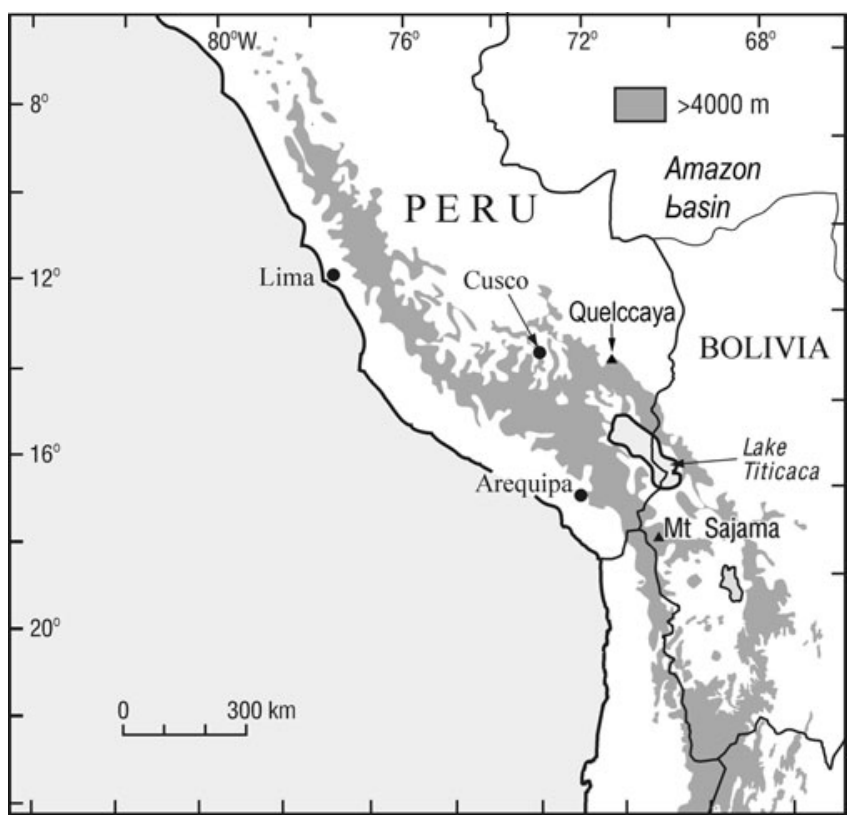

Fig. 1. Map of the central Andes showing the location of Nevado Sajama (adapted from Reese and others, 2003).

\section{STUDY AREA}

Nevado Sajama $\left(18^{\circ} 06^{\prime} \mathrm{S}, 68^{\circ} 53^{\prime} \mathrm{W}\right.$; Mt Sajama in Fig. 1) rises to $6542 \mathrm{~m}$ on the drier, western side of the Bolivian Altiplano. The vegetation of the Altiplano is generally classified as puna grassland (Tosi, 1960). This vegetation type is not homogeneous throughout its range because it is affected by both latitudinal and elevational climatic gradients (Reese and Liu, 2005a). The latitudinal gradient is largely a function of precipitation, with wetter conditions in the northeastern section of the Altiplano (precipitation $>400 \mathrm{~mm} \mathrm{a}^{-1}$ ) and drier conditions in the southwest (precipitation 100-400 $\mathrm{mm} \mathrm{a}^{-1}$ ) (Cabrera, 1968; Seibert, 1998). Grasses (Poaceae) are more prevalent in the wetter sections of the puna along with a higher density of shrubs, while small shrubs (namely Asteraceae) dominate the drier portions (Seibert, 1998; Kuentz and others, 2007). Average annual precipitation at the base of Nevado Sajama is $316 \mathrm{~mm} \mathrm{a}^{-1}$ (Hardy and others, 1998) and the vegetation composition near its base is typical of the dry puna ecosystem.

The elevational facies of the puna have been defined in many ways (Tosi, 1960; Cabrera, 1968; Cuatrecasas, 1968; Troll, 1968; Graf, 1981; Hansen and others, 1984; Reese and Liu, 2005a). Kuentz and others (2007) provide a useful summary of the previous definitions and propose their own detailed categorization. They subdivide the puna into three bioclimatic belts - the supratropical belt (3000-4000 m), the orotropical belt $(4000-4800 \mathrm{~m})$ and the cryotropical belt (4800 $\mathrm{m}$ to snowline) - all three of which can be found near or on the slopes of Nevado Sajama. The upper sections of the supratropical belt have high densities of shrubs, notably from the Asteraceae, Cactaceae, Fabaceae and Solanaceae familes. Small shrubs (especially Asteraceae) continue as a dominant plant in the orotropical belt, though during the wet season or in wetter years herbs (mainly Poaceae) may cover up to $75 \%$ of the soil. This orotropical belt also includes peat bog communities (or 'bofedales'; Baied and Wheeler, 1993) common to the Altiplano, and Polylepis woodlands. The peat bog communities grow in low-lying depressions or around sources of water. Here aquatics like Azolla are common, as well as Plantago, Distichia and members of the Cyperaceae and Apiaceae families (Reese and Liu, 2005a; Kuentz and others, 2007). At Sajama, thin stands of Polylepis tarapacana (Rada and others, 2001) can be found on the slopes up to $\sim 5000 \mathrm{~m}$ (Kessler, 1995). Only a small fraction of the original Andean Polylepis woodlands survive today (Fjeldså and Kessler, 1996), though it is unclear whether climatic or anthropogenic factors through the Holocene contributed to their decline (Hansen and others, 1994). Finally, the cryotropical belt primarily consists of herbs that are highly adapted to intense physical weathering (Kuentz and others, 2007). Here, Azorella (Apiaceae) is quite common, as well as members of the Caryophyllaceae, Malvaceae, Poaceae and Asteraceae families.

While the vegetation zones that surround the mountain are well understood, the source area for the pollen in the ice cap is less certain. Snow accumulation studies on Sajama show that only the summer wet-season precipitation/accumulation (December-March) is represented in the firn (Hardy and others, 2003). However, the loss throughout the year is primarily due to sublimation (Hardy and others, 2003), so dry-season pollen could potentially be present in the firn, as sublimation is thought to concentrate pollen in snow (Liu and others, 2007). Owing to the development of the South American summer monsoon (Zhou and Lau, 1998), the prevailing winds during the accumulation months are decidedly out of the east and northeast (from the eastern Andean slopes and Amazonian lowlands) and therefore explain the high summer precipitation rates which represent over $80 \%$ of the annual total at Sajama (Hardy and others, 1998; Vuille and others, 1998). However, this circulation regime is regularly interrupted by El Niño Southern Oscillation (ENSO) events. During warm-phase (El Niño) conditions, decreased thunderstorm activity and the corresponding decrease in latent heating is thought to weaken the highpressure cell over the Altiplano that produces this easterly flow (Schwerdtfeger, 1961; Gutman and Schwerdtfeger, 1965; Ramage 1968; Dean, 1971; Kreuls and others, 1975; Rao and Erdogan, 1989; Lenters and Cook, 1995). At Sajama, this change in circulation results in drier and windier conditions that are thought to increase sublimation, thus concentrating pollen (Liu and others, 2007). Modern pollen studies from Quelccaya ice cap, southern Peru (Fig. 1), corroborate these findings and show that the pollen assemblage within the ice is also affected by ENSO events (Reese and Liu, 2005b). During El Niño, the pollen assemblage in the ice cap reflects the puna vegetation located on the Altiplano. However, during a normal (nonENSO) year, the pollen assemblage reflects the dense Yungas (tropical forest) vegetation on the eastern Andean slopes and lowlands. This variability, coupled with the problems associated with the long-distance transport of pollen, makes the source region or regions of this pollen impossible to define. Thus, the pollen on Sajama provides a general, regional record of vegetation change for the central Andes. Nevertheless, the record is very useful as it comes from a unique archive, with a different depositional environment and pollen source region than previous Andean pollen records.

\section{METHODS}

In 1997, two long cores were drilled to bedrock and extracted (Thompson and others, 1998) from the summit of Nevado Sajama (Fig. 1). These cores (C-1 and C-2) were drilled $3 \mathrm{~m}$ 


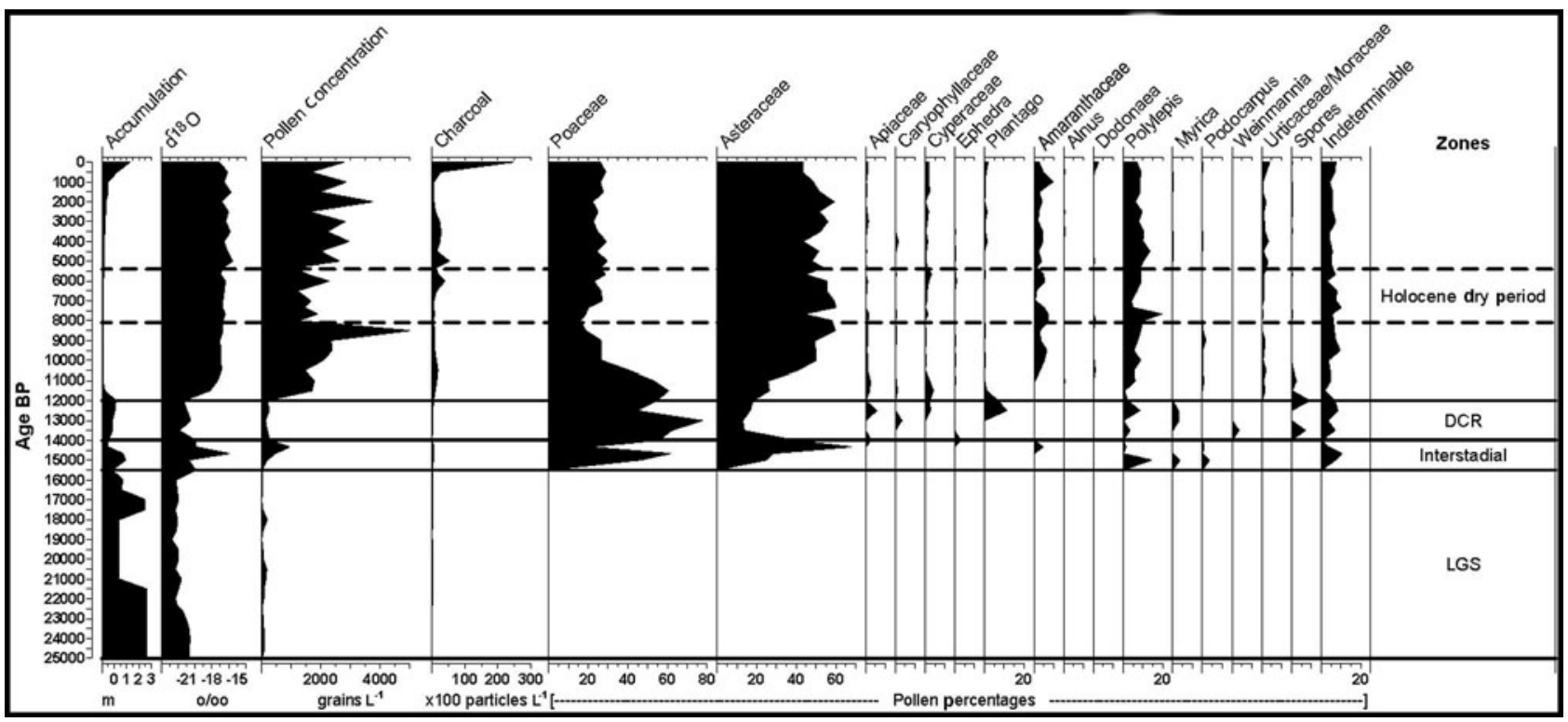

Fig. 2. Pollen diagram from Nevado Sajama.

apart and both were used for our palynological investigation. Although C-2 was used primarily for pollen sampling, samples were taken from C-1 in instances where sections of the primary core had already been heavily sampled. Dating control for the two long cores came from a combination of techniques including ${ }^{3} \mathrm{H}$ (tritium) analysis, physical layer counts, calibrated ${ }^{14} \mathrm{C}$ accelerator mass spectrometry (AMS) dates and stratigraphic $\delta^{18} \mathrm{O}_{(\mathrm{atm})}$ and $\delta^{18} \mathrm{O}_{\text {(water) }}$ correlations with the Greenland Ice Sheet Project 2 (GISP2) core from Greenland (Thompson and others, 1998).

The pollen results for this record were obtained from 249 ice samples that cover the entire $132 \mathrm{~m}$ long Sajama ice core. Standard pollen-processing procedures for meltwater were used (Liu and others, 1998; Reese and Liu, 2002). Each sample was first spiked with Lycopodium marker spores (Stockmarr, 1971), then slowly evaporated down to $50 \mathrm{~mL}$ and transferred into centrifuge tubes. Next, each sample was treated with an acetolysis solution to remove cellulose, stained, and mounted on microscope slides for counting.

Samples range in resolution from 4 months to 550 years of accumulation. To standardize the record, the pollen data were grouped into $\sim 500$ year time aggregates. Though it was impossible to create equal time aggregates throughout the core, all aggregates fall within \pm 50 years of the 500 year interval. This aggregation allows the entire record to be compared with minimal sampling bias.

A Nikon Optiphot microscope (at $400 \times$ magnification) was used for pollen and spore identification. All pollen and spores were counted until a total of 300 grains was obtained. The identifications were verified using pollen keys (Van der Hammen and Gonzalez, 1960; Heusser, 1971; Markgraf and D'Antoni, 1978; Roubik and Moreno, 1991; Colinvaux and others, 1999) and the pollen reference slide library at Louisiana State University. Charcoal particles were counted and are reported, regardless of size, but the majority had maximum diameters of $\leq 50 \mu \mathrm{m}$. Concentrations and percentages were calculated with TILIA software and TGView 2.0 was used to generate the pollen diagram (Fig. 2). The zones on Figure 2 are based on our interpretation of the pollen concentration and percentage data, but the titles for each zone follow the nomenclature of previous published studies on the Sajama ice core (Thompson and others, 1998).

\section{RESULTS AND DISCUSSION Late-glacial stage}

From 25 to $15 \mathrm{ka}$ BP, pollen was absent from the record, or present in only small amounts ( $<8$ grains per sample; Fig. 2 ). This lack of pollen probably reflects very sparse vegetation due to the extremely cold and wet conditions (Gosling and others, 2008), as well as reduced atmospheric partial $\mathrm{CO}_{2}$ pressure (Boom and others, 2001) on the Altiplano during the Late-glacial stage (LGS). Low $\mathrm{CO}_{2}$ pressure has been shown to reduce/slow plant growth, thus potentially reducing the amount of pollen dispersed from these plants. The cordillera bordering the Altiplano was heavily glaciated during this period, which greatly reduced the local plant communities. High accumulation rates during this period would also work to dilute pollen concentrations in the ice core. Regardless, the near absence of pollen in this section makes any reliable interpretation of the paleovegetation very difficult.

\section{Interstadial}

At $15.5 \mathrm{ka}$ BP, the oxygen-isotope data from Sajama indicate the beginning of a short period of warmer and possibly drier conditions that lasted until $\sim 14$ ka BP (Thompson and others, 1998). Vuille and others (2003) have shown that enriched $\mathrm{O}^{18}$ values at Sajama are negatively correlated with precipitation $(r=-0.66)$ and positively correlated with temperature $(r=0.88)$. At $\sim 15 \mathrm{kaBP}$, more pollen is found in the Sajama record and reflects the transition out of LGS conditions. Pollen concentrations range from 279 to 944 grains $\mathrm{L}^{-1}$ and the assemblage consists primarily of Poaceae (grass) and Asteraceae. Though the increase in pollen from these families indicates the postglacial expansion of the puna vegetation community, the distribution was likely still constricted and the cover was probably very sparse. Polylepis pollen also emerges in small quantities and remains a regular taxon throughout the rest of the record. The sporadic presence of Podocarpus and Myrica is likely due to long-distance transport. 
This interstadial period closely matches the BøllingAllerød/Guantiva interstadial event that has been recorded in several South American lake sediment records using a variety of chemical and biological proxies (Van Geel and Van der Hammen, 1973; Van der Hammen, 1974; Helmens and Kuhry, 1986; Van der Hammen and Hooghiemstra, 1995; Baker and others, 2001). However, there is some disagreement among the records as to the moisture characteristics of this event. Records from northern South America show this to be a warm and wet event (Van der Hammen, 1974; Helmens and Kuhry, 1986), while records from the Altiplano show this to be a time of decreased precipitation (Thompson and others, 1998; Baker and others, 2001; Paduano and others, 2003). The pollen evidence in this section of the ice core needs to be interpreted with caution due to low concentration numbers, but may shed additional light on the question of moisture availability during this period.

Several paleoecological studies from the Altiplano have suggested that increases in Poaceae and decreases in Asteraceae indicate wetter conditions (and vice versa) (Betancourt and others, 2000; Latorre and others, 2002, 2003; Reese and others, 2003; Liu and others, 2005; Reese and Liu, 2005a). In rodent middens and surface soils, the use of the Poaceae/Asteraceae ratio as a proxy for moisture conditions may be complicated by differential pollen preservation, but this limitation does not apply to ice-core samples. The Poaceae/Asteraceae proxy follows a real precipitation-driven vegetation gradient on the Altiplano, in which grasses dominate in the northern (wetter) sections of the region while Asteraceae shrubs dominate in the drier southern sections (Seibert, 1998; Kuentz and others, 2007). This ecological relationship forms the basis for our interpretation of the pollen record.

As temperatures warmed at the start of this short interstadial and pollen concentrations begin to rise, grasses dominate the record. We interpret this as a transitional time when the wet conditions during the glacial stage persisted for a few hundred years while temperatures ameliorated. However, toward the end of this period, Asteraceae began to dominate and was coupled with dryness indicators such as increases in Amaranthacae and Ephedra. During this period there is also a decrease in Polylepis, which Graf (1981) linked to drier conditions. Therefore, based on the pollen evidence, we interpret this period to have been both warmer and drier.

\section{Deglacial climatic reversal}

Between 14 and 12 ka BP another climatic change known as the deglacial climatic reversal (DCR; Thompson and others, 1998) was recorded in the Sajama ice core. The $\mathrm{O}^{18}$ values in ice from this period in the Sajama ice core are more depleted and approach LGS levels. This zone is broadly synchronous with other stadial events reported at Río Desaguadero, Bolivia (Rigsby and others, 2005), in Lake Titicaca (Baker and others, 2001) and at Lake Compuerta on the western flank of the Peruvian Andes (Weng and others, 2006). As reflected in the accumulation record at Sajama, this period corresponds to high stands in Lake Titicaca (Baker and others, 2001) and the Uyuni-Coipasa basin (Sylvestre and others, 1999; Placzek and others, 2006) and a period of wet oscillations at Lake Pacucha (Hillyer and others, 2009).

Pollen concentrations in the DCR are close to values in the LGS and range from 130 to 262 grains $L^{-1}$. The pollen percentages are dominated by Poaceae (40-74\%), though high percentages of Asteraceae, Apiaceae, Plantago, Myrica, Polylepis, Caryophyllaceae, Cyperaceae and fern spores (Selaginella and Polypodicaeae-type) are present. The high percentages of Poaceae, along with the presence of Apiaceae and Cyperaceae, corroborate the wet conditions that were thought to exist on the Altiplano. Kuentz and others (2007) found that during wet years, herbs (mainly Poaceae) may represent $75 \%$ of the vegetation cover in the orotropical vegetation zone. In addition to this, wetter conditions would expand the 'bofedales' or peat bog communities common to the Altiplano, where Poaceae, Apiaceae and Cyperaceae occur in abundance.

\section{Holocene}

After $12 \mathrm{kaBP}$, the chemical proxies from the ice core (Thompson and others, 1998) indicate that the climate abruptly shifted to Holocene conditions and temperature and precipitation stabilized relatively quickly at $\sim 11 \mathrm{ka} \mathrm{BP}$. Pollen concentrations in the core increase dramatically to 1500-1800 grains $L^{-1}$, likely reflecting the warmer conditions on the Altiplano. The first notable amounts of charcoal appear at $\sim 12 \mathrm{kaBP}$ and are found consistently throughout the Holocene, reinforcing the notion that fire has been an important ecological agent in the development of central Andean ecosystems (Bush and others, 2005). Though the Holocene transition is fairly abrupt, it is important to note that the pollen percentages for Poaceae and Asteraceae, the two dominant taxa, remained in a state of transition until $10 \mathrm{ka}$ BP when their ratios stabilized near their modern-day levels.

Early Holocene (12-10 ka BP) conditions are marked by an increase in percentages of Asteraceae pollen to an equilibrium level between 40 and $60 \%$. Poaceae declines from its dominance in the late Pleistocene to an equilibrium level between 20 and $30 \%$. We interpret this change as a response to a generally warmer and drier climate, which caused a contraction of the peat bog communities on the Altiplano and allowed the small shrubs that are present on the Altiplano today to replace the herbs common to the DCR. Increases in the Amaranthaceae families and decreases in the Apiaceae and Cyperaceae families support this interpretation (Graf, 1981).

In ice from 10.5 to $9.0 \mathrm{kaBP}$, pollen concentrations steadily increase from 1500 to 2250 grains $\mathrm{L}^{-1}$, then spike to their highest level in the record at 8500 (5000 grains $\mathrm{L}^{-1}$ ). We interpret this as a dry start to the Holocene with steadily increasing moisture levels that culminated with a wet event at $\sim 8.5 \mathrm{ka}$ BP. In an ice cap there are two primary mechanisms that control pollen concentration: (1) pollen production/ influx, which is positively correlated to concentration; and (2) net accumulation, which is negatively correlated. As pollen production increases in the region, so does the amount of pollen that can potentially make it to the ice cap, thus increasing concentration. However, even if the pollen production remains constant in a given year, an increase in net accumulation will dilute the pollen, thereby reducing the pollen concentration. Fortunately, through most of the Holocene, the net accumulation rate on Sajama has been very constant (Thompson and others, 1998). Because of this, the pollen concentration in the Holocene ice most likely reflects plant population density and pollen production. Many sources suggest that moisture is the critical (limiting) factor that determines plant population and pollen productivity on the Altiplano (e.g. Luteyn, 1999); therefore, we 
interpret Holocene pollen concentration as a proxy for moisture availability. Also during this period (10.0-8.5 ka BP) Polylepis steadily increased, supporting the interpretation of decreasing moisture stress on Altiplano vegetation. Graf (1981) noted that increases in Polylepis pollen are not linked to drier conditions. It is important to note that the use of pollen as a moisture proxy should not be misinterpreted as a precipitation indicator, because many other factors (such as temperature, evaporation, cloudiness and wind conditions) contribute to the moisture availability for plants.

Other studies from the Andes show a similar climatic trend during the early Holocene. Low stands have been recorded at $\sim 10 \mathrm{kaBP}$ at Lake Junin (Seltzer and others, 2000), Lake Titicaca (Paduano and others, 2003) and Lake Pacucha (Hillyer and others, 2009). Sediment profiles from these lakes also show increasing amounts of moisture after $10 \mathrm{ka} \mathrm{BP}$, culminating in high stands at $\sim 8.5 \mathrm{ka} \mathrm{BP}$ (Baker and others, 2001; Paduano and others, 2003; Hillyer and others, 2009). Thompson and others (1995) also note a similar moisture trend in the Huascarán ice core, though the wetter conditions there persisted until $7 \mathrm{kaBP}$. Our findings are notably out of synch with the record from Laguna de Chochos, which shows a remarkable low stand between 9.5 and $7.3 \mathrm{ka} \mathrm{BP}$ (Bush and others, 2005).

In ice deposited after $8.5 \mathrm{ka} \mathrm{BP}$, the pollen concentration drops markedly to 1260 grains $\mathrm{L}^{-1}$ and remains below 2000 grains $\mathrm{L}^{-1}$ until $5.5 \mathrm{kaBP}$. We interpret this period as corresponding to the mid-Holocene dry period that has been widely reported across the Andes (Seltzer and others, 1998; Baker and others, 2001; Cross and others, 2001; D'Agostino and others, 2002; Abbott and others, 2003; Paduano and others, 2003; Tapia and others, 2003; Bush and others, 2004; Moreno and others, 2007; Ekdahl and others, 2008; Hillyer and others, 2009; Urrego and others, 2010). This period also corresponds to an interval of marked retreat of Quelccaya ice cap, signaling not only drier but probably warmer conditions as well (Buffen and others, 2009). Several studies have suggested that El Niño was weakened or less active during this period (Moy and others, 2002) and may have exacerbated these dry conditions. Aside from pollen concentration, the percentages of individual taxa do not respond significantly to this event. One notable exception is a sharp decline in Polylepis at $\sim 7$ ka BP. Toward the end of this dry event (6 ka BP) there is a small increase in Cyperaceae and the first significant rise in charcoal. Hillyer and others (2009) found an increased frequency of short wet events or oscillations near the end of the mid-Holocene dry period, and the increase of charcoal and Cyperaceae may corroborate this.

In ice deposited after $5.5 \mathrm{kaBP}$, pollen concentration returns to its pre-dry-period level and maintains these high levels (2000-3500 grains $\mathrm{L}^{-1}$ ) to present day. During this period there are no marked changes in the percentages of individual pollen taxa, signaling relatively stable conditions. Remarkably, this trend holds true for Polylepis, which maintains percentages near $10 \%$ throughout the rest of the Holocene. Most pollen studies in the Andes show declining abundance of Polylepis (e.g. Hansen and Rodbell, 1995; Colinvaux and others, 1997; Bush and others, 2005) in the late Holocene, a trend thought to indicate widespread reductions in populations of Polylepis due to increased fire and other human disturbances (Fjeldså and Kessler, 1996; Cingolani and others, 2008). The consistency of our numbers through the late Holocene may reflect the close proximity of thin stands of Polylepis, which are still present near the base of Sajama today. Also of note is the dramatic increase in charcoal to nearly 230000 particles $L^{-1}$ in the most recent sample. This is undoubtedly the result of anthropogenic burning and ore-smelting (Bush and others, 2005; Cooke and others, 2008).

\section{CONCLUSION}

This study shows that pollen in tropical ice cores can be used as an indicator of vegetation response to glacial/interglacial climate change sequences. Pollen is direct evidence from vegetation and thus adds an important biological proxy to the existing paleoenvironmental record at Sajama. An example of this added contribution is our demonstration that the vegetation response during the DCR was quite different than that seen in the LGS. The ice-core record shows both the DCR and the LGS as cold and wet periods, with the Last Glacial Maximum (LGM) being wetter (Thompson and others, 1998), yet the plants show quite a different response. It can be speculated that the whole area was largely snowcovered during the LGM, eliminating most of the regional vegetation. A large part of the snow cover was likely lost during the warm/dry interstadial such that Poaceae and Polylepis appear to have flourished during the cold and drier DCR. Other examples can be seen in the dominance of dry taxa (Asteraceae, Amaranthaceae) during the BøllingAllerød/Guantiva interstadial, as well as the timing and duration of the vegetation transition into the Holocene.

It is important to note, however, that these pollen data should be interpreted with caution in areas of the core with low pollen concentration or in samples with an overrepresentation of a handful of taxa. For example, in many samples Asteraceae and Poaceae pollen account for $>80 \%$ of the total pollen sum. Though these numbers reflect the overwhelming abundance of these plants on the Altiplano, this greatly limits the percentages of other pollen taxa, reducing their sensitivity as indicators of vegetation change. Another useful parameter in the pollen record is pollen concentration, which can be used as a moisture indicator when net accumulation is stable. At several important transitions (end of LGS, DCR, and start of the Holocene), pollen concentration responded in unison with the $\mathrm{O}^{18}$ and accumulation data from Sajama. However, the causes driving these changes in moisture availability cannot be detected with the pollen alone.

In general, the pollen data corroborate many of the paleoenvironmental changes recorded at Sajama and throughout the Andes. LGS conditions persisted until $\sim 15.5 \mathrm{kaBP}$, followed by a 1500 year period of warmer conditions. Starting at $14 \mathrm{ka}$ BP there was a return to stadial conditions corresponding with the DCR. The beginning of the Holocene at $\sim 12$ ka BP was probably dry, with increasing amounts of moisture until about $8.5 \mathrm{kaBP}$. Low pollen concentrations reflect a dry mid-Holocene from 8.0 to $5.5 \mathrm{kaBP}$, with wetter conditions then re-emerging and holding stable to the present.

One interesting observation is that the timing of the midHolocene dry period (based on the pollen evidence) is slightly out of synch with the spikes in dust and in moisturesensitive soluble anions $\left(\mathrm{SO}_{4}^{-}\right.$and $\left.\mathrm{Cl}^{-}\right)$from the Sajama ice core, which occur between 6 and 2 ka BP (Thompson and others, 1998). Different pollen source regions could account for these differences. Hillyer and others (2009) suggested 
that the mid-Holocene dry event was time-transgressive, occurring earlier in the northern Altiplano and later in the southern Altiplano near Sajama. The pollen at Sajama could represent source regions further to the north and northeast. This would agree with the summer circulation pattern on the Altiplano and also explain the strong correlation between the pollen on Sajama and the Lake Titicaca and Lake Pacucha records (Paduano and others, 2003; Hillyer and others, 2009). Although our data have corroborated the midHolocene dry event from many paleoenvironmental records around the Andes, it is notably out of synch with records from Lago Chaka Kkota and Laguna Viscachani (Abbott and others, 1997, 2000, 2003) and Lake Aricota (Placzek and others, 2001), which are relatively close to Sajama; this asymmetry warrants further investigation. In conclusion, the ice-core pollen record at Sajama is sensitive to climatic changes at this temporal scale, adds depth to the existing Sajama ice-core record, and corroborates many of its findings (based on chemical and physical evidence) with a biological proxy.

\section{ACKNOWLEDGEMENTS}

We thank Mary Davis for ice-core sample preparation, and Mary Lee Eggart and Cliff Duplechin for cartographic assistance. We also thank Sally Horn and an anonymous reviewer for helpful suggestions. This research was jointly funded by the Geography and Regional Science Program, the Paleoclimate Program, and the Americas Program of the US National Science Foundation (NSF grants BCS-9906002, BCS-0117338 and BCS-0217321).

\section{REFERENCES}

Abbott MB, Seltzer GO, Kelts KR and Southon J (1997) Holocene paleohydrology of the tropical Andes from lake records. Quat. Res., 47(1), 70-80 (doi: 10.1006/qres.1996.1874)

Abbott MB, Wolfe BB, Aravena R, Wolfe AP and Seltzer GO (2000) Holocene hydrological reconstructions from stable isotopes and paleolimnology, Cordillera Real, Bolivia. Quat. Sci. Rev., 19(17-18), 1801-1820 (doi: 10.1016/S0277-3791(00)00078-0)

Abbott MB and 9 others (2003) Holocene paleohydrology and glacial history of the central Andes using multiproxy lake sediment studies. Palaeogeogr., Palaeoclimatol., Palaeoecol., 194(1-3), 123-138 (doi: 10.1016/S0031-0182(03)00274-8)

Baied CA and Wheeler JC (1993) Evolution of high Andean puna ecosystems: environment, climate, and culture change over the last 12,000 years in the central Andes. Mt. Res. Dev., 13(2), 145-156

Baker PA and 8 others (2001) The history of South American tropical precipitation for the past 25,000 years. Science, 291(5504), 640-643 (doi: 10.1126/science.291.5504.640)

Betancourt JL, Latorre C, Rech JA, Quade J and Rylander KA (2000) A 22,000-year record of monsoonal precipitation from northern Chile's Atacama Desert. Science, 289(5484), 1542-1546 (doi: 10.1126/science.289.5484.1542)

Boom A, Mora G, Cleef AM and Hooghiemstra H (2001) High altitude $\mathrm{C}_{4}$ grasslands in the northern Andes: relicts from glacial conditions? Rev. Palaeobot. Palynol, 115(3-4), 147-160 (doi: 10.1016/S0034-6667(01)00056-2)

Buffen AM, Thompson LG, Mosley-Thompson ES and Huh KI (2009) Recently exposed vegetation reveals Holocene changes in the extent of the Quelccaya ice cap. Quat. Res., 72(2), 157-163 (doi: 10.1016/j.yqres.2009.02.007)

Bush MB, Silman MR and Urrego DH (2004) 48,000 years of climate and forest change in a biodiversity hot spot. Science, 303(5659), 827-829 (doi: 10.1126/science.1090795)
Bush MB and 8 others (2005) A 17000 -year history of Andean climate and vegetation change from Laguna de Chochos, Peru. J. Quat. Sci., 20(7-8), 703-714 (doi: 10.1002/jqs.983)

Cabrera AL (1968) Ecología vegetal de la puna. In Troll C ed. Geoecology of the mountainous regions of the tropical Americas. Proceedings of the UNESCO Mexico Symposium, 1-3 August 1966, Mexico City. (Colloquium Geographicum 9) Ferd. Dümmers, Bonn, 91-116

Chepstow-Lusty A, Frogley MR, Bauer BS, Bush MB and Herrera AT (2003) A late Holocene record of arid events from the Cuzco region, Peru. J. Quat. Sci., 18(6), 491-502 (doi: 10.1002/jqs.770)

Chepstow-Lusty A, Bush MB, Frogley MR, Baker PA, Fritz SC and Aronson J (2005) Vegetation and climate change on the Bolivian Altiplano between 108,000 and 18,000 yr ago. Quat. Res., 63(1), 90-98 (doi: 10.1016/j.yqres.2004.09.008)

Cingolani AM, Renison D, Tecco PA, Gurvich DE and Cabido M (2008) Predicting cover types in a mountain range with long evolutionary grazing history: a GIS approach. J. Biogeogr., 35(3), 538-551 (doi: 10.1111/j.1365-2699.2007.01807.x)

Colinvaux PA, Bush MB, Steinitz-Kannan M and Miller MC (1997) Glacial and postglacial pollen records from the Ecuadorian Andes and Amazon. Quat. Res., 48(1), 69-78 (doi: 10.1006/ qres.1997.1908)

Colinvaux PA, De Oliveira PE and Moreno Patiño JE (1999) Amazon pollen manual and atlas. Harwood Academic, Amsterdam

Cooke CA, Abbott MB and Wolfe AP (2008) Late-Holocene atmospheric lead deposition in the Peruvian and Bolivian Andes. Holocene, 18(2), 353-359 (doi: 10.1177/0959683607085134)

Cross SL, Baker PA, Seltzer GO, Fritz SC and Dunbar RB (2001) Late Quaternary climate and hydrology of tropical South America Inferred from an isotopic and chemical model of Lake Titicaca, Bolivia and Peru. Quat. Res., 56(1), 1-9 (doi: 10.1006/ qres.2001.2244)

Cuatrecasas J (1968) Paramo vegetation and its life forms. In Troll C ed. Geo-ecology of the mountainous regions of the tropical Americas. Proceedings of the UNESCO Mexico Symposium, 1-3 August 1966, Mexico City. (Colloquium Geographicum 9). Ferd. Dümmers, Bonn, 163-186

D'Agostino K, Seltzer G, Baker P, Fritz S and Dunbar R (2002) LateQuaternary lowstands of Lake Titicaca: evidence from highresolution seismic data. Palaeogeogr., Palaeoclimatol., Palaeoecol., 179(1-2), 97-111 (doi: 10.1016/S0031-0182(01)00411-4)

Dean GA (1971) The three-dimensional wind structure over South America and associated rainfall over Brazil. Tech. Rep. LAFE164. Department of Meteorology, Florida State University, Tallahassee

Ekdahl EJ, Fritz SC, Baker PA, Rigsby CA and Coley K (2008) Holocene multidecadal- to millennial-scale hydrologic variability on the South American Altiplano. Holocene, 18(6), 867-876 (doi: 10.1177/0959683608093524)

Fjeldså J and Kessler M (1996) Conserving the biological diversity of Polylepis woodlands of the highlands of Peru and Bolivia: a contribution to sustainable natural resource management in the Andes. Nordic Foundation for Development and Ecology, Copenhagen

Garreaud RD (1999) Multiscale analysis of the summertime precipitation over the central Andes. Mon. Weather Rev., 127(5), 901-921 (doi: 10.1175/1520-0493(1999)127<0901: MAOTSP $>2.0 . C O ; 2)$

Garreaud RD (2000) Cold air incursions over subtropical South America: mean structure and dynamics. Mon. Weather Rev., 128(7), 2544-2559 (doi: 10.1175/1520-0493(2000)128<2544: CAIOSS $>2.0 . \mathrm{CO} ; 2)$

Garreaud R, Vuille M and Clement AC (2003) The climate of the Altiplano: observed current conditions and mechanisms of past changes. Palaeogeogr., Palaeoclimatol., Palaeoecol., 194(1-3), 5-22 (doi: 10.1016/S0031-0182(03)00269-4)

Gosling WD, Bush MB, Hanselman JA and Chepstow-Lusty A (2008) Glacial-interglacial changes in moisture balance and the impact on vegetation in the Southern Hemisphere tropical 
Andes (Bolivia/Peru). Palaeogeogr., Palaeoclimatol., Palaeoecol., 259(1), 35-50 (doi: 10.1016/j.palaeo.2007.02.050)

Graf K (1981) Palynological investigations of two post-glacial peat bogs near the boundary of Bolivia and Peru. J. Biogeogr., 8(5), 353-368

Grosjean M (2001) Mid-Holocene climate in the south-central Andes: humid or dry? Science, 292(5526), 2391 (doi: 10.1126/ science.292.5526.2391a)

Gutman G and Schwerdtfeger W (1965) The role of latent and sensible heat for the development of a high pressure system over the subtropical Andes, in the summer. Meteorol. Rundsch., 18(3), 69-75

Hanselman JA, Gosling WD, Paduano GM and Bush MB (2005) Contrasting pollen histories of MIS $5 \mathrm{e}$ and the Holocene from Lake Titicaca (Bolivia/Peru). J. Quat. Sci., 20(7-8), 663-670 (doi: 10.1002/jqs.979)

Hansen BCS and Rodbell DT (1995) A Late-glacial/Holocene pollen record from the eastern Andes of northern Peru. Quat. Res., 44(2), 216-227 (doi: 10.1006/qres.1995.1066)

Hansen BCS, Wright HE, Jr and Bradbury JP (1984) Pollen studies in the Junín area, central Peruvian Andes. Geol. Soc. Am. Bull., 95(12), 1454-1465 (doi: 10.1130/0016-7606(1984)95<1454: PSITJA $>2.0 . C O ; 2)$

Hansen BCS, Seltzer GO and Wright HE, Jr (1994) Late Quaternary vegetational change in the central Peruvian Andes. Palaeogeogr., Palaeoclimatol., Palaeoecol., 109(2-4), 263-285 (doi: 10.1016/ 0031-0182(94)90179-1)

Hardy DR, Vuille M, Braun C, Keimig F and Bradley RS (1998) Annual and daily meteorological cycles at high altitude on a tropical mountain. Bull. Am. Meteorol. Soc., 79(9), 1899-1913 (doi: 10.1175/1520-0477(1998)079<1899:AADMCA >2.0.CO;2)

Hardy DR, Vuille M and Bradley RS (2003) Variability of snow accumulation and isotopic composition on Nevado Sajama, Bolivia. J. Geophys. Res., 108(D22), 4693 (doi: 10.1029/ 2003JD003623)

Helmens KF and Kuhry P (1986) Middle and late Quaternary vegetational and climatic history of the paramo de Agua Blanca (Eastern Cordillera, Colombia). Palaeogeogr., Palaeoclimatol., Palaeoecol., 56(3-4), 291-335 (doi: 10.1016/0031-0182(86) 90100-8)

Heusser C (1971) Pollen and spores of Chile: modern types of the Pteridophyta, Gymnospermae and Angiospermae. University of Arizona Press, Tucson, AZ

Hillyer R, Valencia BG, Bush MB, Silman MR and Steinitz-Kannan $M$ (2009) A 24,700-yr paleolimnological history from the Peruvian Andes. Quat. Res., 71(1), 71-82 (doi: 10.1016/j.yqres. 2008.06.006)

Holmgren CA and 7 others (2001) Holocene vegetation history from fossil rodent middens near Arequipa, Peru. Quat. Res., 56(2), 242-251 (doi: 10.1006/qres.2001.2262)

Kessler M (1995) The genus Polylepis (Rosacaea) in Bolivia. Candollea, 50(1), 131-171

Kreuels R, Fraedrich K and Ruprecht E (1975) An aerological climatology of South America. Meteorol. Rundsch., 28, 17-24

Kuentz A, Galán de Mera A, Ledru M-P and Thouret J-C (2007) Phytogeographical data and modern pollen rain of the puna belt in southern Peru (Nevado Coropuna, Western Cordillera). J. Biogeogr., 34(10), 1762-1776 (doi: 10.1111/j.1365-2699. 2007.01728.x)

Latorre C, Betancourt JL, Rylander KA and Quade J (2002) Vegetation invasions into absolute desert: a 45,000 yr rodent midden record from the Calama-Salar de Atacama basins, northern Chile (lat $22^{\circ}-24^{\circ} \mathrm{S}$ ). Geol. Soc. Am. Bull., 114(3), 349-366 (doi: 10.1130/0016-7606(2002)114<0349:VIIADA> 2.0.CO;2)

Latorre C, Betancourt JL, Rylander KA and Quade J (2003) A vegetation history from the arid prepuna of northern Chile (22$23^{\circ} \mathrm{S}$ ) over the last 13500 years. Palaeogeogr., Palaeoclimatol., Palaeoecol., 194(1-3), 223-246 (doi: 10.1016/S0031-0182(03) 00279-7)
Lenters JD and Cook KH (1995) Simulation and diagnosis of the regional summertime precipitation climatology of South America. J. Climate, 8(12), 2988-3005 (doi: 10.1175/1520-0442 (1995)008<2988:SADOTR>2.0.CO;2)

Liu KB, Yao Z and Thompson LG (1998) A pollen record of Holocene climatic changes from the Dunde ice cap, QinghaiTibetan Plateau. Geology, 26(2), 135-138 (doi: 10.1130/00917613(1998)026<0135:APROHC>2.3.CO;2)

Liu KB, Reese CA and Thompson LG (2005) Ice-core pollen record of climatic changes in the central Andes during the last 400 years. Quat. Res., 64(2), 272-278 (doi: 10.1016/j.yqres. 2005.06.001)

Liu KB, Reese CA and Thompson LG (2007) A potential pollen proxy for ENSO derived from the Sajama ice core. Geophys. Res. Lett., 34(9), L09504 (doi: 10.1029/2006GL029018)

Luteyn JL (1999) Páramos: a checklist of plant diversity, geographical distribution, and botanical literature. New York Botanical Garden Press, New York

Markgraf V and D'Antoni HL (1978) Pollen flora of Argentina: modern spore and pollen types of Pteridophyta, Gymnospermae, and Angiospermae. University of Arizona Press, Tucson, AZ

Moreno A and 8 others (2007) A 14 kyr record of the tropical Andes: the Lago Chungará sequence $\left(18^{\circ} \mathrm{S}\right.$, northern Chilean Altiplano). Quat. Int., 161(1), 4-21 (doi: 10.1016/j.quaint. 2006.10.020)

Mourguiart P and Ledru M-P (2003) Last Glacial Maximum in an Andean cloud forest environment (Eastern Cordillera, Bolivia). Geology, 31(3), 195-198 (doi: 10.1130/0091-7613(2003)031 $<0195$ :LGMIAA>2.0.CO;2)

Moy CM, Seltzer GO, Rodbell DT and Anderson DM (2002) Variability of El Niño/Southern Oscillation activity at millennial timescales during the Holocene epoch. Nature, 420(6912), 162-165 (doi: 10.1038/nature01194)

Paduano GM, Bush MB, Baker PA, Fritz SC and Seltzer GO (2003) A vegetation and fire history of Lake Titicaca since the Last Glacial Maximum. Palaeogeogr., Palaeoclimatol., Palaeoecol., 194(1-3), 259-279 (doi: 10.1016/S0031-0182(03)00281-5)

Placzek C, Quade J and Betancourt JL (2001) Holocene lake-level fluctuations of Lake Aricota, southern Peru. Quat. Res., 56(2), 181-190 (doi: 10.1006/qres.2001.2263)

Placzek C, Quade J and Patchett PJ (2006) Geochronology and stratigraphy of late Pleistocene lake cycles on the southern Bolivian Altiplano: implications for causes of tropical climate change. Geol. Soc. Am. Bull., 118(5-6), 515-532 (doi: 10.1130/ B25770.1)

Quade J, Rech J, Betancourt J and Latorre C (2001) Response to Grosjean: mid-Holocene climate in the south-central Andes: humid or dry? Science, 292(5526), 2391 (doi: 10.1126/science. 292.5526.2391a)

Rada F and 8 others (2001) Low-temperature resistance in Polylepis tarapacana, a tree growing at the highest altitudes in the world. Plant, Cell Environ. 24(3), 377-381 (doi: 10.1046/j.1365-3040. 2001.00685.x)

Ramage CS (1968) Role of a tropical 'maritime continent' in the atmospheric circulation. Mon. Weather Rev., 96(6), 365-370 (doi: 10.1175/1520-0493(1968)096<0365:ROATMC> 2.0.CO;2)

Rao GV and Erdogan S (1989) The atmospheric heat source over the Bolivian plateau for a mean January. Bound.-Layer Meteorol., 46(1-2), 13-33 (doi: 10.1007/BF00118444)

Reese CA and Liu KB (2002) Pollen dispersal and deposition on the Quelccaya ice cap, Peru. Phys. Geogr., 23(1), 44-58 (doi: 10.2747/0272-3646.23.1.44)

Reese CA and Liu KB (2005a) A modern pollen rain study from the central Andes region of South America. J. Biogeogr., 32(4), 709-718 (doi: 10.1111/j.1365-2699.2005.01183.x)

Reese CA and Liu KB (2005b) Interannual variability in pollen dispersal and deposition on the tropical Quelccaya ice cap. Prof. Geogr., 57(2), 185-197 (doi: 10.1111/j.0033-0124.2005. 00471.x) 
Reese CA, Liu KB and Mountain KR (2003) Pollen dispersal and deposition on the ice cap of Volcán Parinacota, southwestern Bolivia. Arct. Antarct. Alp. Res., 35(4), 469-474

Rigsby CA, Bradbury JP, Baker PA, Rollins SM and Warren MR (2005) Late Quaternary palaeolakes, rivers, and wetlands on the Bolivian Altiplano and their palaeoclimatic implications. J. Quat. Sci., 20(7-8), 671-691 (doi: 10.1002/jqs.986)

Roubik DW and Moreno JEP (1991) Pollen and spores of Barro Colorado Island. (Monographs in Systematic Botany 36) Missouri Botanical Garden Press, St Louis, MO

Schwerdtfeger W (1961) Strömungs- und Temperaturfeld der freiern Atmosphäre über den Anden. Meteorol. Rundsch., 14, 1-6

Seibert P (1998) Guide de l'Amérique du Sud: paysages et végétation. Eugen Ulmer, Paris

Seltzer GO, Baker PO, Cross S, Dunbar R and Fritz S (1998) Highresolution seismic reflection profiles from Lake Titicaca, PeruBolivia: evidence for Holocene aridity in the tropical Andes. Geology, 26(2), 167-170 (doi: 10.1130/0091-7613(1998)026 $<0167$ :HRSRPF>2.3.CO;2)

Seltzer GO, Rodbell D and Burns S (2000) Isotopic evidence for late Quaternary climatic change in tropical South America. Geology, 28(1), 35-38 (doi: 10.1130/0091-7613(2000)28<35:IEFLQC> 2.0.CO;2)

Stockmarr J (1971) Tablets with spores used in absolute pollen analysis. Pollen Spores, 13(4), 615-621

Sylvestre F, Servant M, Servant-Vildary S, Causse C, Fournier M and Ybert JP (1999) Lake-level chronology on the southern Bolivian Altiplano $\left(18^{\circ}-23^{\circ} \mathrm{S}\right)$ during late-glacial time and the early Holocene. Quat. Res., 51(1), 54-66 (doi: 10.1006/qres. 1998.2017)

Tapia PM, Fritz SC, Baker PA, Seltzer GO and Dunbar RB (2003) A late Quaternary diatom record of tropical climatic history from Lake Titicaca (Peru and Bolivia). Palaeogeogr., Palaeoclimatol., Palaeoecol., 194(1-3), 139-164 (doi: 10.1016/S0031-0182 (03)00275-X)

Thompson LG and 7 others (1995) Late-glacial stage and Holocene tropical ice-core records from Huascarán, Peru. Science, 269(5220), 46-50 (doi: 10.1126/science.269.5220.46)

Thompson LG and 11 others (1998) A 25,000-year tropical climate history from Bolivian ice cores. Science, 282(5395), 1858-1864 (doi: 10.1126/science.282.5395.1858)

Thompson LG and 8 others (2006) Abrupt tropical climate change: past and present. Proc. Nat. Acad. Sci. USA (PNAS), 103(28), 10 536-10543 (doi: 10.1073/pnas.0603900103)

Tosi JA (1960) Zonas de viva natural en el Perú: memoria explicativa sobre el Mapa Ecológico del Perú. (Instituto
Interamericano de Ciencias Agricolas de la OEA, Zona Andina, Issue 5, Boletin Técnico 5). Organización de Estados Americanos, Washington, DC

Troll C (1968) The cordilleras of the tropical Americas: aspects of climatic, phytogeographical and agrarian ecology. In Troll C ed. Geo-ecology of the mountainous regions of the tropical Americas. Proceedings of the UNESCO Mexico Symposium, 1-3 August 1966, Mexico City. (Colloquium Geographicum 9). Ferd. Dümmers, Bonn, 15-56

Urrego D, Bush MB and Silman MR (2010) A long history of cloud and forest migration from Lake Consuelo, Peru. Quat. Res. 73(2), 364-373 (doi: 10.1016/j.yqres.2009.10.005)

Van der Hammen T (1974) The Pleistocene changes of vegetation and climate in tropical South America. J. Biogeogr., 1(1), 3-26

Van der Hammen T and Gonzalez E (1960) Upper Pleistocene and Holocene climate and vegetation of the 'Sabana de Bogotá' (Colombia, South America). Leidse Geol. Med., 25, 261-315

Van der Hammen T and Hooghiemstra H (1995) The El Abra stadial, a Younger Dryas equivalent in Colombia. Quat. Sci. Rev., 14(9), 841-851 (doi: 10.1016/0277-3791(95)00066-6)

Van Geel B and Van der Hammen T (1973) Upper Quaternary vegetational and climatic sequence of the fuquene area (Eastern Cordillera, Colombia). Palaeogeogr., Palaeoclimatol., Palaeoecol., 14(1), 9-92 (doi: 10.1016/0031-0182(73)90064-3)

Vuille M (1999) Atmospheric circulation over the Bolivian Altiplano during dry and wet periods and extreme phases of the Southern Oscillation. Int. J. Climatol., 19(14), 1579-1600 (doi: 10.1002/(SICI)1097-0088(19991130)19:14<1579::AIDJOC441>3.0.CO;2-N)

Vuille M, Hardy DR, Braun C, Keimig F and Bradley RS (1998) Atmospheric circulation anomalies associated with 1996/1997 summer precipitation events on Sajama Ice Cap, Bolivia. J. Geophys. Res., 103(D10), 11 191-11204 (doi: 10.1029/ 98JD00681)

Vuille $\mathrm{M}$ and 6 others (2003) Modeling $\delta^{18} \mathrm{O}$ in precipitation over the tropical Americas: 2. Simulation of the stable isotope signal in Andean ice cores. J. Geophys. Res., 108(D6), 4175 (doi: 10.1029/2001JD002039)

Weng C, Bush MB, Curtis JH, Kolata AL, Dillehay TD and Binford MW (2006) Deglaciation and Holocene climate change in the western Peruvian Andes. Quat. Res., 66(1), 87-96 (doi: 10.1016/ j.yqres.2006.01.004)

Zhou J and Lau K-M (1998) Does a monsoon climate exist over South America? J. Climate, 11(5), 1020-1040 (doi: 10.1175/ 1520-0442(1998)011<1020:DAMCEO>2.0.CO;2) 